\title{
Stope Design for Conservation of Mineral and Safety in Underground Manganese Mine - A Case Study of Munsar Mine of MOIL Limited
}

${ }^{*}$ G.G. Manekar, ${ }^{2}$ C.B. Atulkar, ${ }^{3}$ S.K. Sarkar, ${ }^{4}$ Anil Singh Rajput

GM (Mine-Planning), ED (Technical), Chief Manager (Geology), Manager (Geology) MOIL Limited, Nagpur

Email: ggmanekar61@gmail.com,atulkar@moil.nic.in,sksarkar.moil@gmail.com , anilsingh.moil@gmail.com

Received: 20th November 2019, Accepted: 31st January 2020, Published: 29th February 2020

\begin{abstract}
MOIL Limited is the major manganese producer of the country. Manganese is mined chiefly by underground mining. Cut and Fill method of stopping is adopted in underground mines along with sill and barrier pillars to protect the levels. Valuable manganese ore is locked in sill pillars and to stope design analysis was conducted to improve reserves. Models were prepared with modified stopping methods for stability analysis. This paper presents the outcome of the study.
\end{abstract}

Keywords

Stope Stability, Modeling, Reserves

\section{Introduction}

MOIL is producing various grades of manganese ore from 7 underground. The depth of operation ranges from $154 \mathrm{~m}$ to moderate $353 \mathrm{~m}$. Horizontal cut and fill method of stoping with post filling by hydraulic sand stowing is adopted.

The underground operations of all the mines have been commenced phase wise by entry through adit, incline and vertical shafts. This is due the changes of stress magnitude at different depth and it has enabled for changes of method of stopping from sill pillar to development of drifts in wall rocks for stope preparation.

The Munsar Mine of MOIL Limited is being worked since 1903. The total lease hold area of the mine is 140.49 ha.. The geological formations of the area belong to Munsar Formation of Sausar Group. At present, the manganese ore is being produced from the underground sections of 70' $\mathrm{L}$, (-) 30' $\mathrm{L}$ and below levels (-) 130' $\mathrm{L}$, () $230^{\prime} \mathrm{L}$ and (-) 330' $\mathrm{L}$ are under development stage. The level interval is $30 \mathrm{~m}$. These levels are now attached with vertical shaft sunk at Ch. 2600. Horizontal cut and fill method of stoping with post filling by hydraulic sand stowing is being practiced. The lease plan of the mine is appended in Figure 1.

\section{Geology}

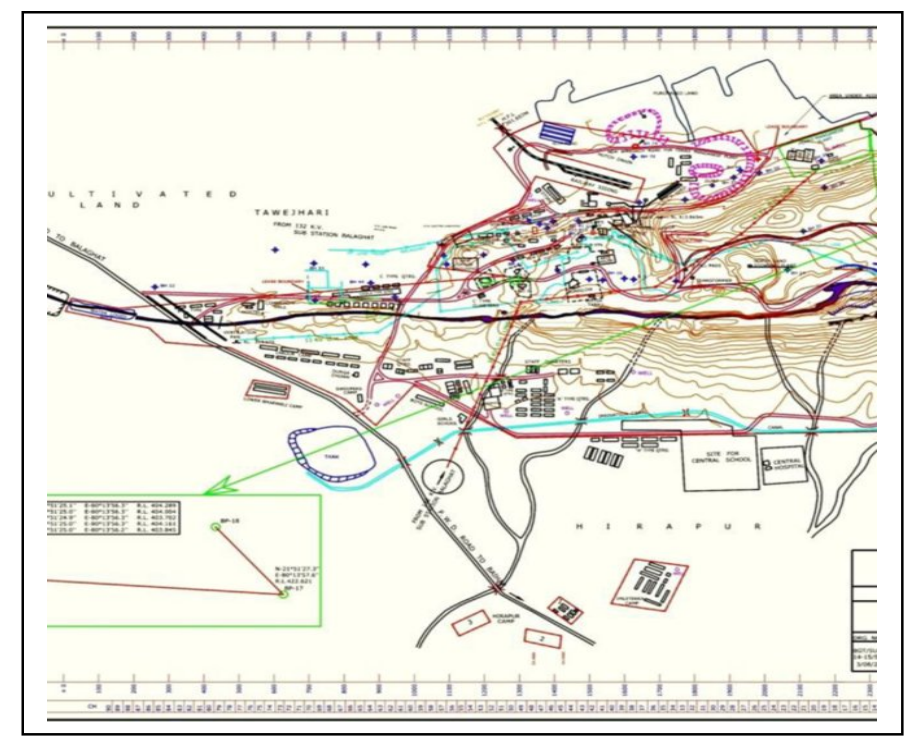

Figure 1: Composite-Lease-Plan

The Precambrian rocks of the Munsar area have a special significance in the stratigraphy of India. The occurrence of "typical schistose rocks" containing gondites and manganese ores, named as Munsar Formation of 
the Sausar Group (Narayanswami et al. 1963). The metasedimentary bands forming the Munsar hill extend in an E-W direction. Horizon belongs to the Munsar Formation is an assemblage of muscovite-biotite schist, muscovite-sillimanite-schist, Banded Braunite Quartzite (BBQ) and Gondite, with manganese-ore. Schistosity defined by parallel arrangement of flaky and prismatic minerals is a conspicuous structural feature in the area. The manganese ore horizons of the Munsar mine are located in the Munsar stage arenaceous schistose rocks and is isoclinals folded into tight anticline and syncline. The manganese ore horizons in the western and central parts are exposed on the higher ground of the Munsar hills. The ore horizons are inter-banded with schistose and gneissose rocks, which were part of the original arenaceous-argillaceous sediments, extensively metamorphosed with associated manganiferous sediments. The said gneiss is primarily composed of Quartz, Biotite, Orthoclase and few minor minerals. Arenaceous schistose rocks are extensively developed in the hanging wall side of the ore horizon. The schists are composed of Quartz and Muscovite with some pink coloured Feldspar imparting gneissic appearance. Distinct bands of Quartz schist and Quartzite are present in the schist. The footwall rock consisting of Sillimanite Muscovite Schists, which are mainly composed of Muscovite with some Quartz and Sillimanite, are well foliated. The footwall rock is persistent along entire strike length of the ore body. The graphic lithology of a borehole in the mine is shown in Figure 2. [5]

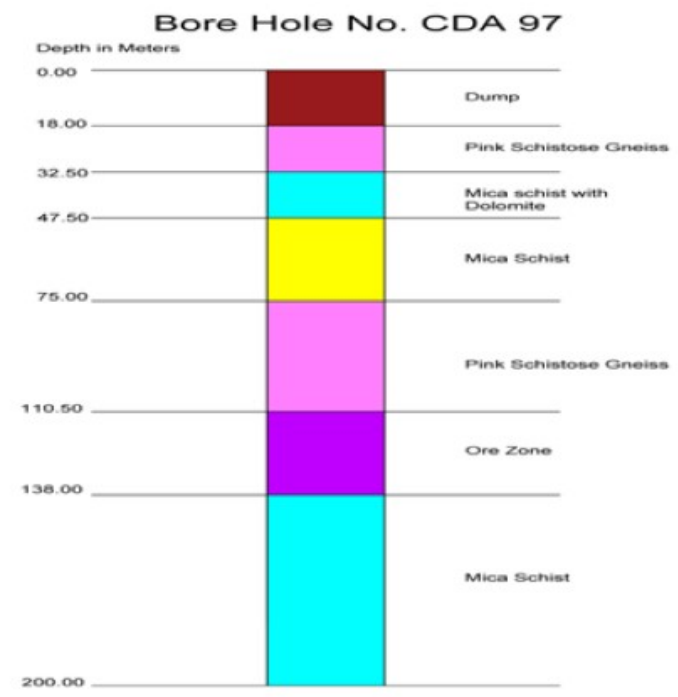

Figure 2: Lithology of Manganese Deposit at Munsar Mine (MOIL Report, Jan, 2018)

\section{Methodology for Rockmass Investigations}

To design the new stope parameters at Munsar Mine, for placement of haulage road size $3.6 \mathrm{~m} \mathrm{x} 2.4 \mathrm{~m}$ in footwall rock located $15-20 \mathrm{~m}$ away from the ore body contact, cross cut of size $2.4 \mathrm{~m} \mathrm{x} 2.1 \mathrm{~m}$ placed $30 \mathrm{~m}$ interval and winzes of size $2.1 \mathrm{~m} \times 1.8 \mathrm{~m}$ located $60 \mathrm{~m}$ interval, the rock mechanics investigations has been carried out through National Institute of Rock Mechanics (NIRM) in the year 2014 - 2016. The engineering geological mapping in working stope blocks was done in between $70^{\prime} \mathrm{L}$ to 170 ' $\mathrm{L}$ to evaluate support system and excavation methodology. The geological cross section between $70^{\prime} \mathrm{L}$ and $170^{\prime} \mathrm{L}$ from Ch.2850 to Ch.3050 were collected for the strike length of $60 \mathrm{~m}$ from $70^{\prime} \mathrm{L}$. The general strike direction of the ore body found that EastWest $\left(\mathrm{N} 70^{\circ} \mathrm{W}-\mathrm{S} 70^{\circ} \mathrm{E}\right)$ and the dip varies from $60^{\circ}$ to $70^{\circ}$ due $\mathrm{N} 20^{\circ} \mathrm{E}$. The ore body is being mined along the strike and dip. Both the hangwall and the footwall consist of quartz mica schist, whereas at some places both hangwall and footwall are consisting of mica schist. Ore body is discontinuous and width of the ore body is also not uniform, and it varies from $5 \mathrm{~m}$ to $7 \mathrm{~m}$ with bulging and pinching. The ore body exhibits well-developed bedding marked by alternate bands of spessattite, rhodonite, and manganese ores. Numerous quartz veins intersect the ore body and the wall rocks. The thickness of the individual bands varies from $2 \mathrm{~cm}$ to $30 \mathrm{~cm}$. Bedding is also well developed in quartz mica schist/quartzite. Schistocity is well developed in schist of Munsar Formations throughout the area. The bedding/ foliation plane has a general east-west strike and steep northern dip. Lineation made up by parallel arrangement of platy and prismatic grains such as micas and hornblende, and also of the elongated grains of quartz and feldspar is commonly observed. The ore is hard, and is siliceous in nature. The contact between the ore body and the mica schist is incompetent, whereas the contact between the ore body with quartz mica schist is competent, site photograph is placed as Figure 3. [4] 


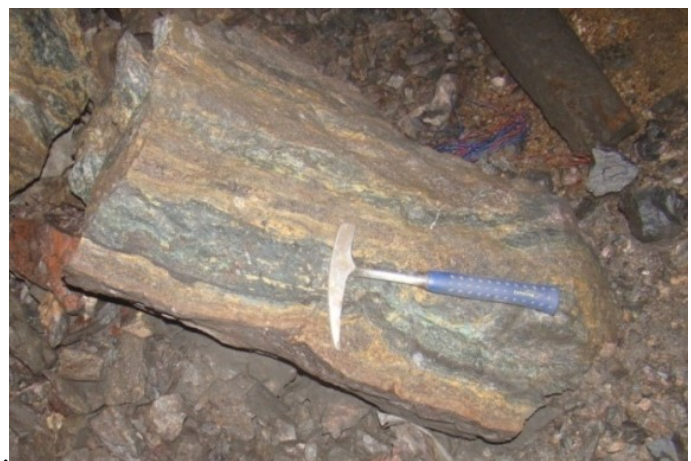

Figure 3: Banded Texture (Foliation) in Ore Zone, Alternate Bands of Mn-ore, and Manganiferous

Physico-Mechanical Properties

Quartzite etc.

Core samples of these rocks were tested at NIRM laboratory as per ISRM suggested methods to determine their physico-mechanical properties. The conducted test results are presented in Table 1.

\begin{tabular}{|c|c|c|c|c|}
\hline Location & Rock description & $\begin{array}{l}\text { Density } \\
\mathrm{kg} / \mathrm{m}^{3}\end{array}$ & $\begin{array}{l}\text { Tensile strength } \\
\qquad(\mathrm{MPa})\end{array}$ & $\begin{array}{c}\text { Compressive strength } \\
\text { (UCS) } \\
(\mathrm{MPa})\end{array}$ \\
\hline Hangwall & Quartz mica schist & $\begin{array}{c}2785.5 \\
(2743-2828) \\
\end{array}$ & $\begin{array}{l}13.50(1) \\
13.10(1)\end{array}$ & $155(1)$ \\
\hline Ore zone & Mn ore & $\begin{array}{c}4081 \\
(3859-4303) \\
\end{array}$ & $\begin{array}{l}23.10 \text { (1) } \\
14.20 \text { (II) }\end{array}$ & $250(1)$ \\
\hline Foot wall & Mica schist & $\begin{array}{c}2809 \\
(2783-2835) \\
\end{array}$ & $\begin{array}{l}15.9 \text { (I) } \\
10.00 \text { (II) }\end{array}$ & $43(1)$ \\
\hline Location & $\begin{array}{c}\text { Young's } \\
\text { Modulus (GPa) }\end{array}$ & $\begin{array}{l}\text { Poisson's } \\
\text { ratio }\end{array}$ & Cohesion (MPa) & Friction Angle (Degree) \\
\hline Hangwall & $63(1)$ & $\begin{array}{c}0.27(1) \\
-\end{array}$ & 34.00 (II) & $53.50(11)$ \\
\hline Ore zone & $153(1)$ & $\begin{array}{c}0.23(1) \\
-\end{array}$ & $38.00(11)$ & $57.40(11)$ \\
\hline Foot wall & $26(I)$ & $\begin{array}{c}0.26(1) \\
-\end{array}$ & 14.00 (II) & $29.20(\mathrm{II})$ \\
\hline
\end{tabular}

Table 1: Geo-Mechanical Properties of the Wall Rocks and Ore Body from Bore Hole EM-37 of Munsar Mine

\section{Rockmass Classification}

The rock mass has been characterized using Q-system and Bieniawski RMR. [1] Estimation of support requirement for the modified stope design was made using the above two rockmass classification systems. It is observed that the average RMR values of footwall, hang wall and ore body obtained value is presented in Table 2.

\begin{tabular}{|c|c|c|}
\hline \multicolumn{3}{|c|}{ Geo-technical Parameters of wall rocks and ore body for Q-system } \\
\hline Location & Rock description & Q-Value \\
\hline Hangwall & $\begin{array}{c}\text { Mica schist/ Quartz mica schist/ Rodonite with } \\
\text { mica schist }\end{array}$ & $6.06-9.38$ (Fair) \\
\hline Ore zone & Mn-ore body & $22.5-66.67$ (Good - Very Good) \\
\hline Footwall & Quartz mica schist/ Mica schist & $4.75-9.37$ (Fair) \\
\hline \multicolumn{3}{|c|}{ Geo-technical Parameters of wall rocks and ore body for RMR } \\
\hline Location & Rock description & RMR \\
\hline Hangwall & $\begin{array}{c}\text { Mica schist/ Quartz mica schist/ Rodonite with } \\
\text { mica schist }\end{array}$ & 59 (Fair) \\
\hline Ore zone & Mn-ore body & $51-61$ (Fair - Good) \\
\hline Footwall & Quartz mica schist/ Mica schist & $33-56$ (Poor - Fair) \\
\hline
\end{tabular}

\section{Table 2: Obtained Q Value and RMR}

\section{Empirical Design}

The maximum stope width of $7 \mathrm{~m}$ is considered for the modified stope design for the mine. The excavation support ratio (ESR) is taken as 1.6. It can be observed from the ' $Q$ ' chart, which is shown in Figure 4 that the 
region falls in unsupported area for $6 \mathrm{~m}$ stope width. However, considering the damage due to blasting and other unforeseen geological effects, systematic bolting is found correct for new stope application in which the haulage road and cross cut is placed in the foot wall rock. [2]

Based on the RMR chart proposed by Bieniaski $(1989,1993)$ for the span, a stand-up time, it has been examined for the RMR 56 of ore body. It is found that the stand up time for an average stope width of $7 \mathrm{~m}$ is between one week and one month. However, the stope is supported with $1.5 \mathrm{~m}$ long rock bolts and hence the actual standup time for the stope width will be much higher than that shown in the RMR chart. [7]

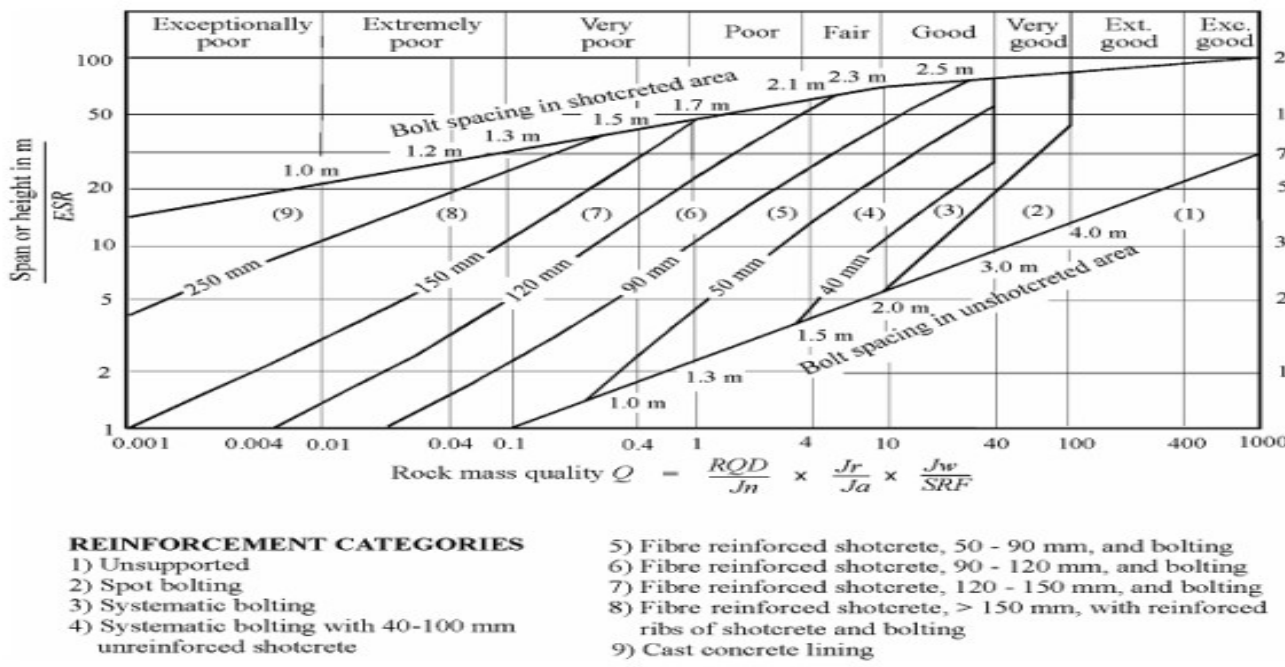

Figure 4: Rockmass Classification and Support as per Q Chart

\section{Numerical Modeling}

With a view to ascertain the stability of crown pillar in stope block of $30 \mathrm{~m}$ height, $60 \mathrm{~m}$ stope length in strike direction and considering max width of ore body $7 \mathrm{~m}$, a 2-dimensional numerical modeling has been performed. To study the efficacy of the rock bolt support and to examine the stability of the crown pillar when the entire stope is excavated and the back fill is in place. To be on conservative side, maximum width of the stope is considered for the modeling. For the insitu stress conditions, vertical loading was calculated for vertical stresses and the horizontal stresses were taken as twice the vertical stresses (Raju, G.D. et al 2016). The cut and fill sequence as practiced in the mine is simulated. Rock bolts of $1.5 \mathrm{~m}$ long are installed with $2 \mathrm{~m}$ spacing as practiced in the mine. [6] The condition of the roof after 4 lifts is shown in Figure 5. The condition of the crown pillar and the rock bolts at the end of the final lift is shown in Figure 6. The rock bolts are lightly loaded and none of the bolts yielded after nearly half of the stope is mined out. Also no significant deformations or instability of the roof was observed. [3] This result of model suggests that the rock bolts at $2 \mathrm{~m}$ spacing are efficient in controlling the back and thus not allowing any instability. However, this model does not take in to account the blasting effects. It can also be observed that the designed crown pillar is highly safe and stable with the rock bolt supports after full excavation and the rock bolts at this stage also are lightly loaded and have enough strength to accommodate any unforeseen loads imposed on the crown pillar.

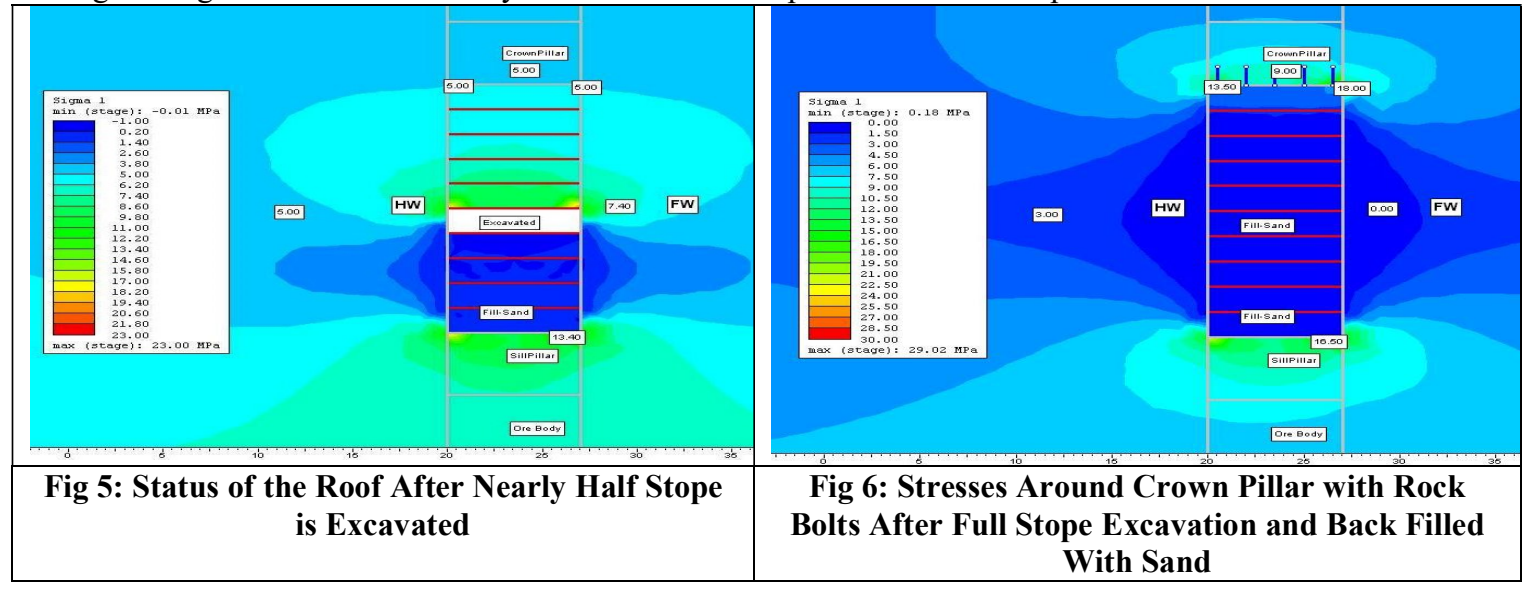


The maximum induced stress due to mining is of the order of $23 \mathrm{MPa}$. The induced stress is very minimal when compared to the rockmass strength thus not posing any instability problems in the stope during the stoping operation. The maximum induced stress due to mining is of the order of $30 \mathrm{MPa}$. This induced stress is not significant when compared to the rockmass strength and hence the stability of the crown pillar is achieved with the designed thickness.

\section{Result}

\section{Modified Stope Design}

Haulage drive of size $3.4 \mathrm{~m} \times 2.1 \mathrm{~m}$ has been developed in footwall rock and is placed $20 \mathrm{~m}$ away from ore body. Cross cuts of size $2.4 \mathrm{~m} \times 2.1 \mathrm{~m}$ are driven from haulage road to intersect the ore body from foot wall to hang wall. The cross cuts interval is $30 \mathrm{~m}$. The raise/ winzes are placed at $60 \mathrm{~m}$ interval. The modified strike length of stope is $60 \mathrm{~m}$. Rock bolt support system with LHD machines will be deployed for mechanical handling of run of mine.

\section{Suggested Support System}

Rock bolt support system of $1.5 \mathrm{~m}$ long at $2 \mathrm{~m}$ spacing in haulage road, cross cut, ore drive and stope back in square pattern is being introduced. $5 \mathrm{~m}$ thick crown pillar is being designed with a safe conservative estimate with FOS of 1.5. Rock mechanics instrumentation work for installation of Multi Point Bore Hole Extensometer from upper level and Strain Bar installation at lower level are in progress.

The maximum stable unfilled volume at any point of the stoping operation is estimated to be 840 cubic meter. This has generated new avenue for introduction of LHD for mechanical handling of ROM in the stope for better productivity.

\section{Conclusions}

After implementations new support design in haulage road, cross cut and in stope back, the mineable reserves have increased as at lower level sill pillar requirement has been eliminated. This has resulted in improvement in production and productivity at Munsar mine. It has also resulted in introduction of LHD. With instrumentation support there may be possibility of reducing barrier pillar thickness to four meters in future.

\section{References}

1. Barton, N. and E. Grimstad (1976), the Q system following 20 years of application NMT support selection, Indi-Norwegian Workshop on Rock Mechanics, KGF, India, pp 1-9

2. Bieniawski, Z.T., (1973), Engineering Classification of Jointed Rock Masses, Trans S Afr. Institute, Civil Engr., 15

3. Manekar G.G., (2018), In house 3-D analysis of subsidence parameters of Munsar Mine, MOIL,

4. MOIL Report (1994), Modified Mining Plan prepared under Mineral Concession Rules 1960, 28 p.

5. Ramakrishna, M. and R. Vaidynadhan. (2010), Geology of India. Vol. 1. Geol. Soc. India, Bangalore, 556p.

6. Numerical Modelling of rock support for mines, Loren J Lorig, Workshop on Managing Excavation Stability through Design, Analysis and Monitoring, Organized by MEA, Nagpur Chapter, 24 September, 2018.

7. Stability of Spilway cut slopesat Dhauliganga H E Project, Dr Gopal Dhawan, B D Patni, All India Seminar on Slope strability issues in Opencast mining and Civil engineering, Organized by NIT, Rourkela, 2015. 